5. Vannice $J$. L., Leoinson $A$. D. Properties of the human hepatitis $B$ virus enhancer: position effects and cell-type nonspccificity // J. Virol. - 1988-62, N 4-P. 13051313.

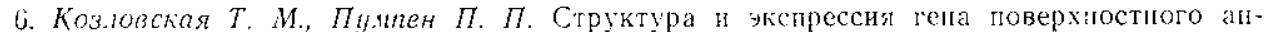
тигена вируса гентата $B$ человека// Молекуляр. бнология-1986.-0, № 4C. $884-901$.

7. Shahid f., Aleem S. The human hepatitis B virus cnhaneer requires trans-acting cellular factor(s) for activity// Mol. and Cell. Biol-1980-6, N 2.- P. 710-715

Ин-т молекияр. биологии и генетики АН УССР, Киев

По.тучнио 24.07 .89

УЛК $577.352 .27: 57.086 .3$

К. М. Билгч, Д. М. Иродов, В. А. Кордюм

НЕКОТОРЫЕ УЛЬТРАСТРУКТУРНЫЕ АСІЕКТЫ ІІРЯМОЙ ИНЪЕКЦИИ ЛИПОСОМ, СОДЕРЖАЩИХ ПЛАЗМИДНУЮ ДІК, В ПЕЧЕНЬ МЫІІИ

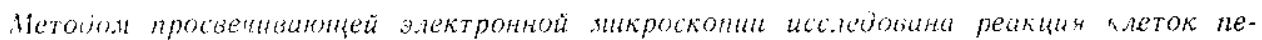

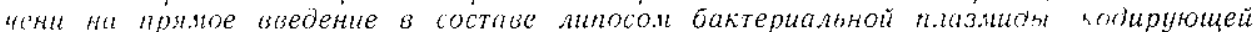

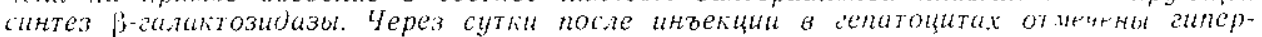

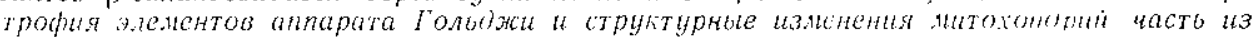

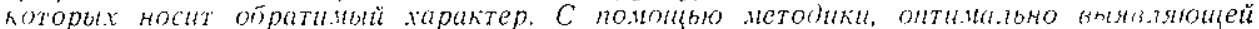

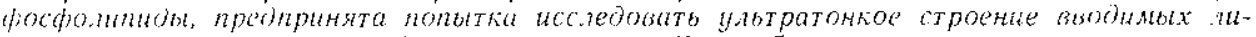

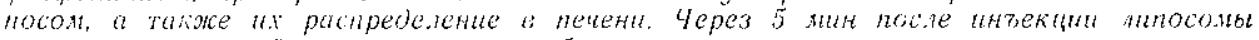

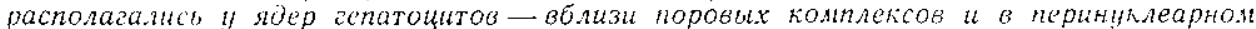

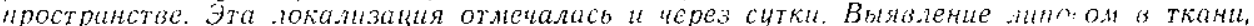

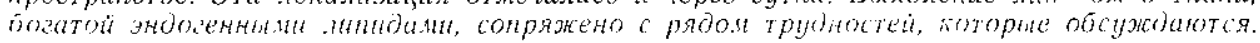

Введение. Ограпичснназ пропицаемость фосфолипидылх мсмбрап позволяет использовать липосомы в качестве носителей физиологически активных вещсств, обеспечивающих дозированное поступлене послсдиих в определениы орган. Варьируя состав липосом, можио паправленно влиять на избирателыност их накопления в опрсделеныы клетках печени [1]. Ранее было высказано предположение [2], что прямая инъекция липосомной суспензии в печень предпочтисльнсе внутривенпой, так как в этом случае липосомы непосредственно контактируют с гелатоцитами, обеспечивая доставку экзогенной ДНК в эти клетки.

механизмы взаимодействия липосом с клетками к настоящему зремени пзучснл достаточно полно [3, 4]. Следует, однако, заметить, "то реже других для выяснения этих механизмов применялся мето: гросвечивающей электронной микроскопин. Такое обстоятельство обтясняется, с одной стороны, методической сложностью стабилизации хрупких липосом в ходе проводки и заливки $[5,9]$, с другой - сушсственной трудностью в дальнсйшем наблюдении за лилосомами в ткінях с активным эндоцитозом. В обход второго затруднения ряд нослепователей предпочитает работать со сравнительно простыми модельными системами [5-7]. Однако на подступах к гениотерапевтическим исслсдованяям [8] становится все болсе очевидиої нсобхогимость электронно-микроскопического контроля качества вводимых липосом, нх распределения в ткани животных и возможных реакций разлицных ультраструктур клетки на вводимый генетический матернал.

Целью настояшей работы явилось изученше ультратопкої организации липосом, приготовленных методом Са-ЭДТА, их распределения в ткани псчени при прямом введения, а также реакци ультраструктур па плазиндную ДНК, инъецируемую в cociaве липосом.

Материалы и методы. В работе пспользовали ДНК плазмиды рQАA293, содержащей lacZ- гел Escherichia colt, кодирующй синтез бактернальной $\beta$-галгактозидазы. Глазмиу заключали в липосомы следующего состава $(\%)$ : лецитн -70 , холестерин -.. 20, денитнл-фосфат - 9, фосфатндит-этаноламин - 1. Основной сиособ приготовлсния - калыиевая плавка с последуюпей обработкой ЭДТА. Был также апроби- 


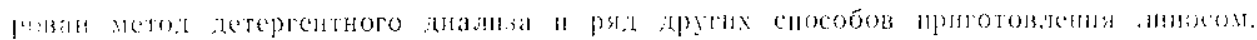

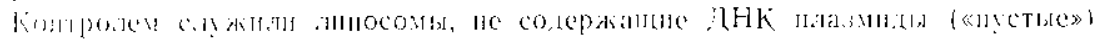

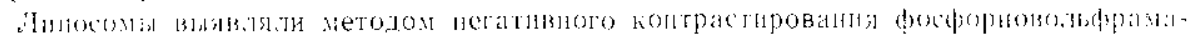

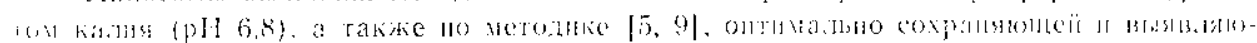

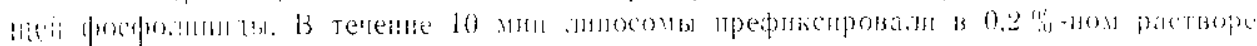

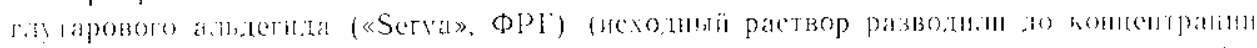

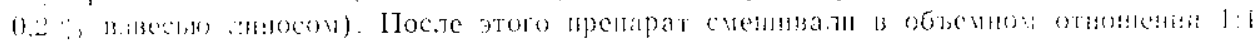

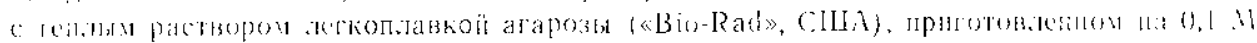

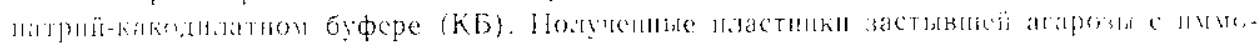

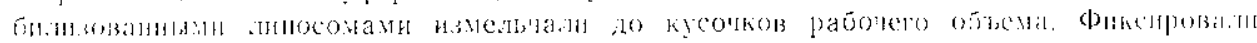

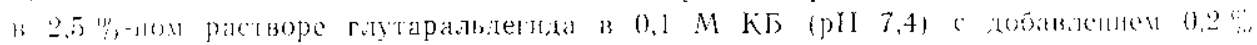

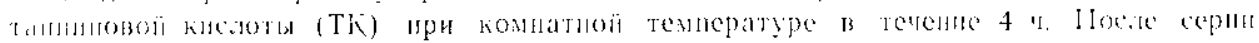

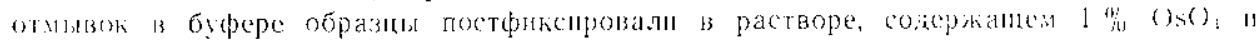

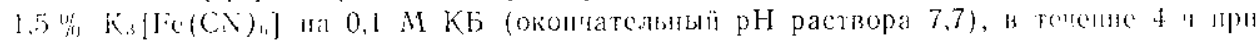

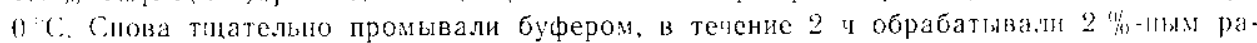

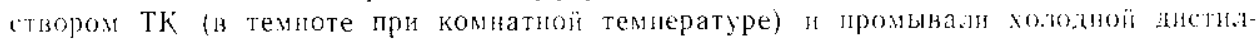

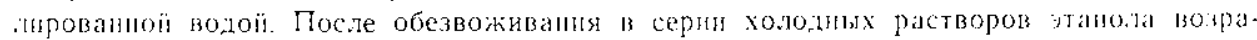

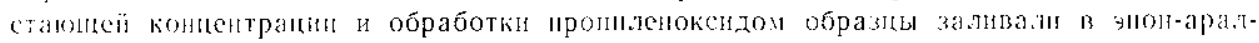

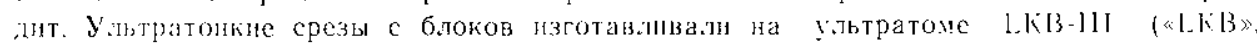

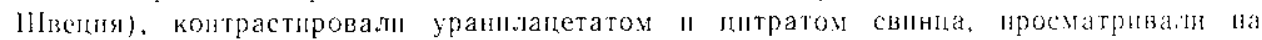

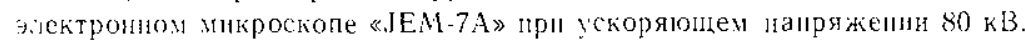

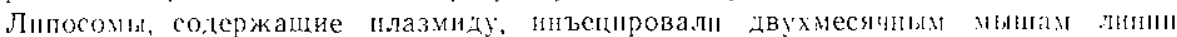

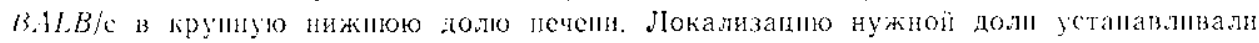

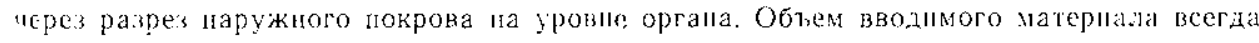
(истав.ля.л 60 мкл на особь, в случае ппъецирования плазмиды вволимый матернал содержал 300 мкг лигидов и 10 мкг ДНК. Контролем служили животныс, которым вво-

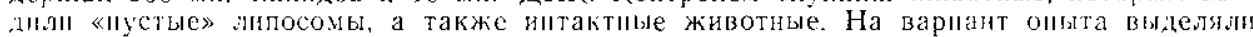

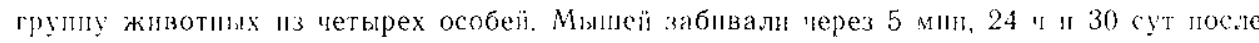
ниьекіни.

Д.ля ириготовления пренаратов ткан иссекали из участков печени, н которы й вво-

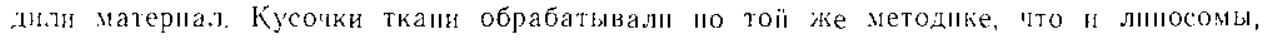

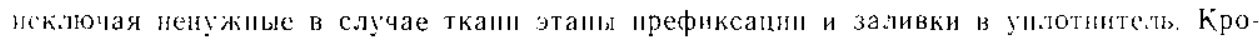

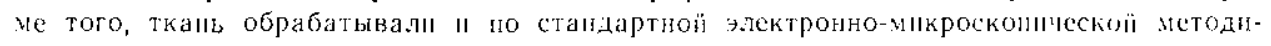

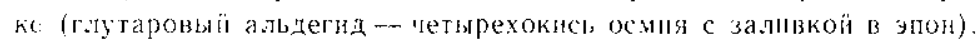

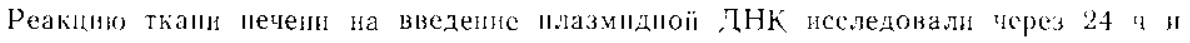
30 сут у тех мынеї, где пролукт экенресын был заранее тестирован методом пмму-

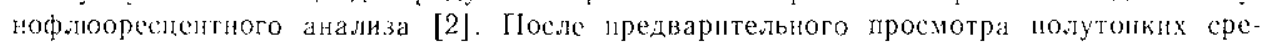
зов дия далныёней обработки пыбнрали периферические зоны долек, отлитапнеся

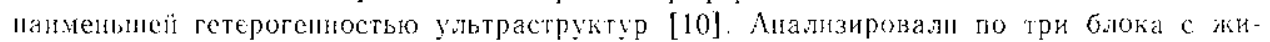

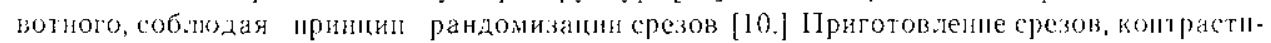

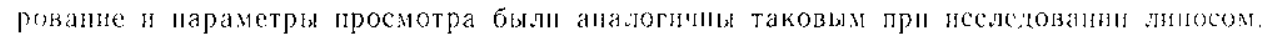

Результахы и обсуждение. С т ре ні е ли посои. Синтатся, что кальциевая плавка осуществлется в мягких физиологияских усповиях н приготовленные этим способом линосомы можно с успехом пспользовать для захвата лабильных биополимеров [3]. Необходимыӥ цля осуществления кальцневой плавки отрицатеыьый заряд привносится ,децитил-фосфатом. Некоторую избыточность этого отрицательнro заряіа с услехом снимает микродобавка фосфатидил-этаноламина.

Негативное контрастирование поззолило оценит препарат как достаточно гомогенный, без крупных агрегатов, с размером везикул от 150 до 250 нм. Малый троцент везикул с окрашенной водной полостью разрешает сделать косвенное заключение о первонатальной целостности мембран в большинстве липосом, полунаемых данным способом (рис. $1, a)$.

Анализ ультратонких срезов дает представление о внутренней ламеллярной организации и о рабохем объеме липосом. Процесс образования липосом протекает, вероятно, в две стадин. Снерва пол влиянием кальция исходные озвученные липосомы агрегирутот с образованием складчатых мультиламеллярных структур (рис. 1, б). Прн обработе ЭДТА эти структуры переходят в большие одно-, хву- и 


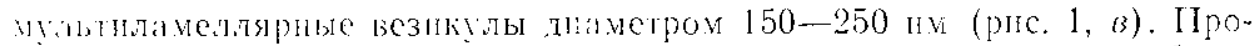

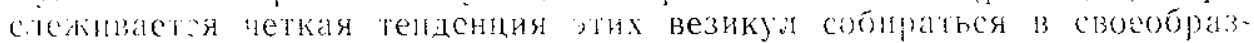

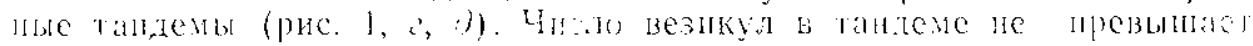

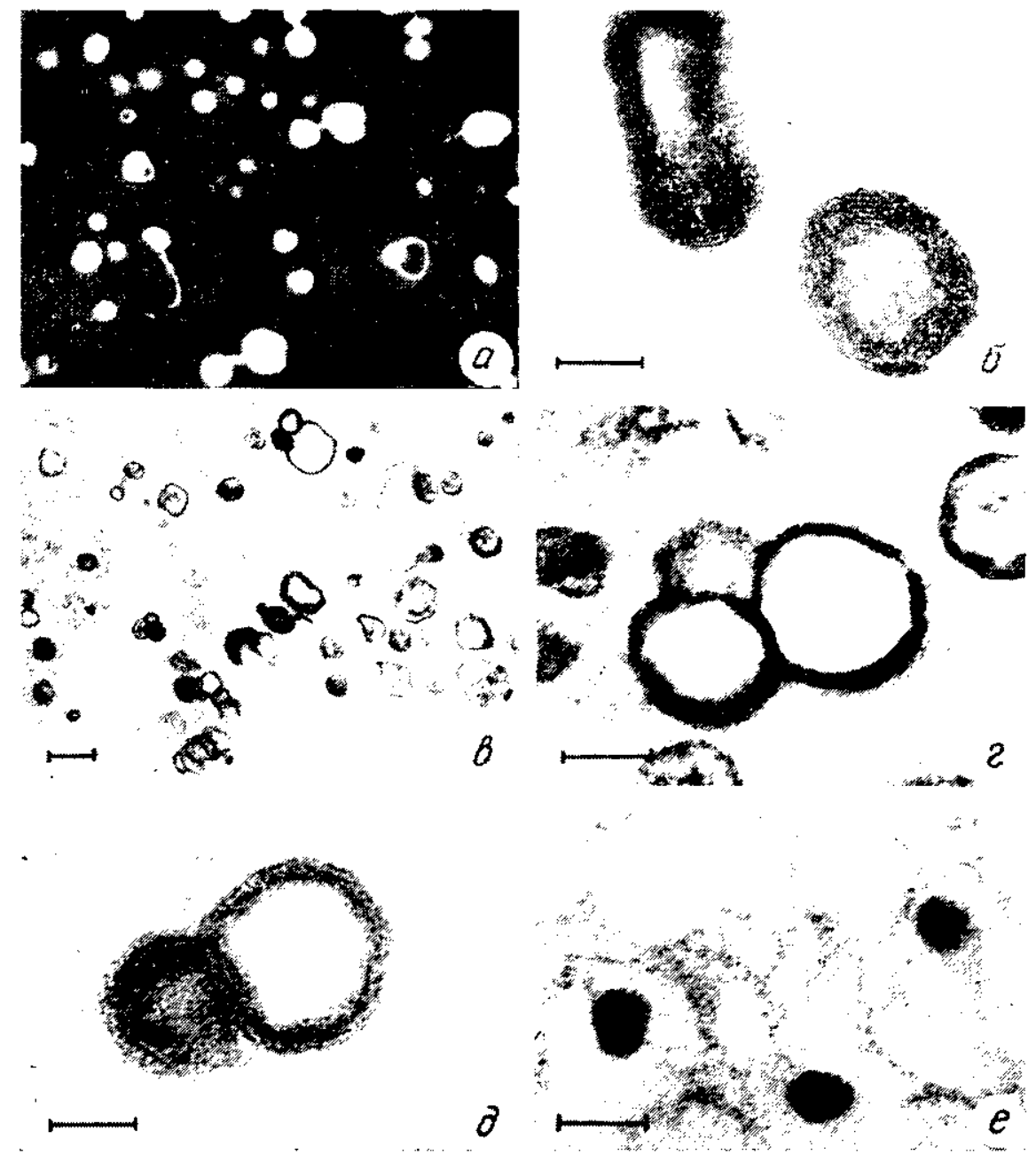

Pнс. 1. Фракция липосом, приготовлениых методами Са-ЭЛТА $(a-\vartheta)$ и детергентного днализа (e); $a$--- пегативное контрастирование, $\ 32000$, маснтаб 0,3 мкм; $\sigma-$ c-- срезы :нносом, иммобнлнзованных в агарозе и зафиксированых по методике «таннновия кистота-- ферронианнд осмня»: $\sigma-$ липосомы после обработки Са, $\times 86000$, маситаб 0,12 мкм: 3-- то же, Са-Э,ДТА, Х22000, маситаб 0,22 мкм: $2-$ типосомиы тайіем, $\times 71000$, масштаб 0,15 мкм; 0,05 мкм; $e-X 102000$, маснгтаб 0,1 мкм

Fig. 1. Fraction of liposomes produced by Ca-EDTA methods (a-d) and detergent diaiysin methed $(e, \times 102000$, bar $-0.1 \mu \mathrm{n}) ; a$ - negative contrast, $\times 32000$, bar $-0.3 \mu m ; 6-\varepsilon$ : sectims of liposomes immobilized in agarose and fixed by tannic-ferrocyanide $\mathrm{OsO}_{3}$ method: 0 - liposomes after $\mathrm{Ca}+$ treatment, $\times 86000$, bat $-0,12 \mu m$; 8 - liposomes afte: Ca-EDT.1 treatment, $\times 22000$, bar $-0.22 \mu m ; \quad z-$ - 2 tandems» of liposomes, $\times 71000$. bar - $0.15, \mathrm{~mm} ; e$ - the same $-\times 102000$, bar -- $0.1 \mu \mathrm{m}$

трех. На срезе полость одпой или двух липосом, составляющих тандем, оказывастся вскрытой, тогда как одна-две другие - залолнены иультиламеллярной намоткой. Очевидно, такая картина отражает прохождение плоскости среза. Хотя толщипа среза и средний диаметр лигосомы - величины сопоставимые, тем не иенес каждая везикула срезается в 2-4 приема. Этим, очевидно, объясняется налинис на гцепаратах определенного процента «горбушек», т. е. верхушечных срезов. Что жс касается тандемов, то, не исключая агрегирования, предположительнее было бы сцитать их продуктом «сшивки», сопровожыасмой обобшествленисм мембран. 


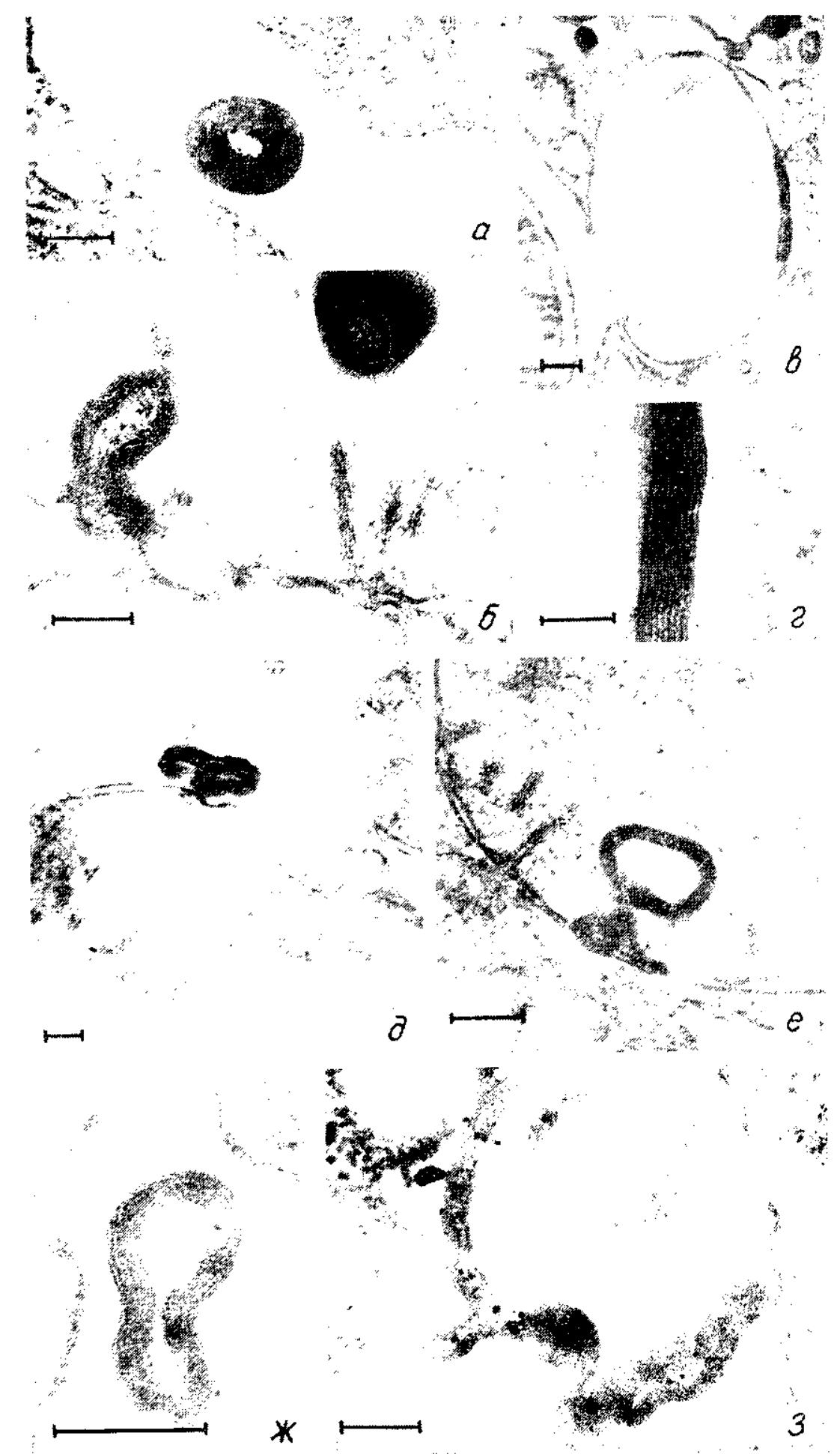

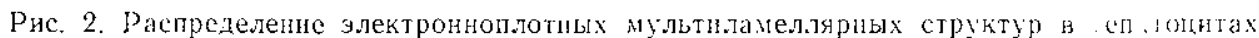

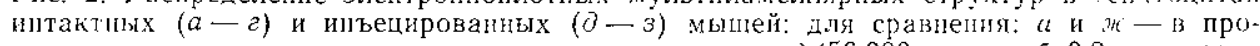
свете канальцев эндоглазнатического ретикулума, $a-\chi 56000$, маситаб 0,2 мкм; $\times 120000$, масштаб 0,16 мкм; 6 н $\partial, e-$ наружной и внутренней мембран мнтохонц-

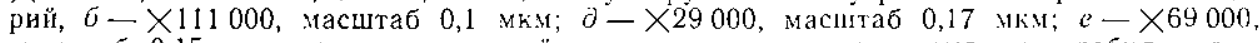
масштаб 0,15 мкм; 6 , $а$ и $3-$ окаймляюшне эндогенную липиднуо глобулу, $8-$ $\times 25000$, масштаб 0,2 мкм; $2-X 111000$, масштаб 0,1 мкм, 3- Х63000, масштай 0,15 мкм. Длительность всех опытов 5 нни после прямої пиъекции линосом

Fig. 2. Distribution of electron-dense multilamellar structures in the hepatocytes of in. tact $(a-2)$ and injected $(j-3)$ mice. (Fixation according to tannic-ferrocyanid $\mathrm{OsO}_{4}$ method). To compare: $a$ and $x-i n$ the lumen of endoplasmic reliculum; $\sigma$ and $\theta, e \cdots$ 
Наши данные несколько расходятся со сводкой [3], где получаемые этим способом липосомы характеризуются как большие одноламеллярные: в потучаемых нами образцах количество ламелл варьирует.

Три тругих апробированных нами способа не дали положительных результатов. Так, например, при детергентном диализе получается достаточно стабильный препарат мультиламеллярных липосом, липғенных внутренней полости (рис. $1, e)$.

Р аспределение липосом в тк аин. Двухступенчатал обработка танниновой кислотой в сочетании с фиксацией в OsFeCN прияае гамеллярным фосфолипидным структурам повышенцю эле ктронную плотность, что позволяет легко идентифицировать іг прл любом уровне контрастирования ткани в срезе.

При анализе образцов печени интактных мышсй, которым липосом не вводили, были получены достаточно неожиданные результаты. В гепатоцитах этих мышей встречались электронноплотные олиголамеллярные везикулы, покализованныс в просветах расширениых ка нальцсв гладкого эндоплазматического ретикулума (рис. $2, a$ ), в цитоплазме вблизи митохондрий и в матриксе митохогдрй (рис. 2,6 ). Размеры этих структур, пернодичность укладки ламелл, электропная плотность были настолько сходны с соответствующими параметрами липосом, что это дало нам повод назвать их псевдолилосомами (IIЛ). Kроме того, в цитоплазме интактных мыней эндогенные липидныс глобулы передко окаймлены электропноплотными мультиламеллярными тяжами (рпс. 2, в). Плотность укладкі мембрап здесь такая же, как в липосомах и в ПЛ (рнс. 2, г), но протяженность тяжей больше.

у подопытных животных, которым инъецировали липосомы («пустые» и содержашие плазииду), на всех сроках пследоваиия в гепатоцитах паблюдались олнголамеллярные везикулы вышеописапной формы, ультраструктурной организацин и покализации (рнс. $2, \partial-$ 3). Размеры этих структур соответствовали ранее описанным размерам пипосом, ие превыпая $250 \mathrm{~mm}$ (за нсключением памеллярных тяжей вокруг липидных глобул).

Разница между опытом и чистым контролсм состояла в том, что при экспознции ткани с липосомами в теченис 5 мин слутаи контакта везикул с митохондрнямі (рнс. 2, д) и их включення в матрикс (рис. $2, e$ ) наблюдались знапштельно чаше. В то же время в гепатоиитах нптактных мышей быма очевиднси структурная связь ПЛ с митохондриальнй мемораной (pxс, 2,6$)$.

Ни в опыте, ні в коптроле не отмехалось случаев включения элсктронноплотных везикул в цитоплазматическис вакуоли, вторичные лизосомы нли их объединения с эндоцитозными пузырьками.

Черсз 5 мин послс шньекции липосом электрониолотные олиголамеллярные везикулы прослеживались вблизи ядер гепатоцитов y ялсрих пор ил в расширегия псринуклеарного пространства (рнс. 3, a). Через сутки после пнъекции липосом пастота встречаемости везикул у ядер гепатоцитов еще достаточно велика (рис. 3, в), множественые скоплени прослеживаются между микроворсинками желчэпи канальцев (рис. 3, б), а также во́лизи эндотелиальйї выстилки щространства Диссе. Қ 30-тым сут после инъекции везикулы у ядер не об́ларужены.

Структуры, локализованные у ядра, всегда уплощены, выхинут, слоистенные липосомам иросвет и первоначальные сферические очертания тастичн или полпостьо утрачены (рнс. 3, a), но во всех случаях сохраняются высокая электронная плотность ॥ периодичиость ламеллярной намотки (рис. $3,2, \partial$ ). Нередко в липосомах у ялер про-

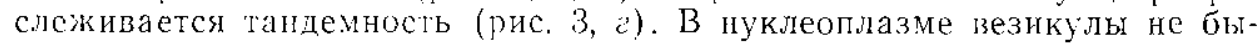

near the onter and inner membranes of mitochondria; $B$, $a$ and 3 -brordering the endo. genic lipil droplet, $a-\times 56000$, har $0.2 \mathrm{~mm}, \sigma-\times 111000$, har $0.1 \mu \mathrm{m}, a-\times 25000$, $0.2 \mu \mathrm{m} ; e^{-} \times 111000$, bar $0.1 \mu \mathrm{m} ; \partial-\times 29000$, har $0.17 \mu \mathrm{m} ; \quad-\times 69000$, har $0.15 \mu \mathrm{m}$; $4-\times i 20000$, bar $0.16 \mu m ; 3-\times 63000$, bar $0.15 \mu m$. The experiment in all the case is 5 minutes after direct injection of liposomes into tissue 


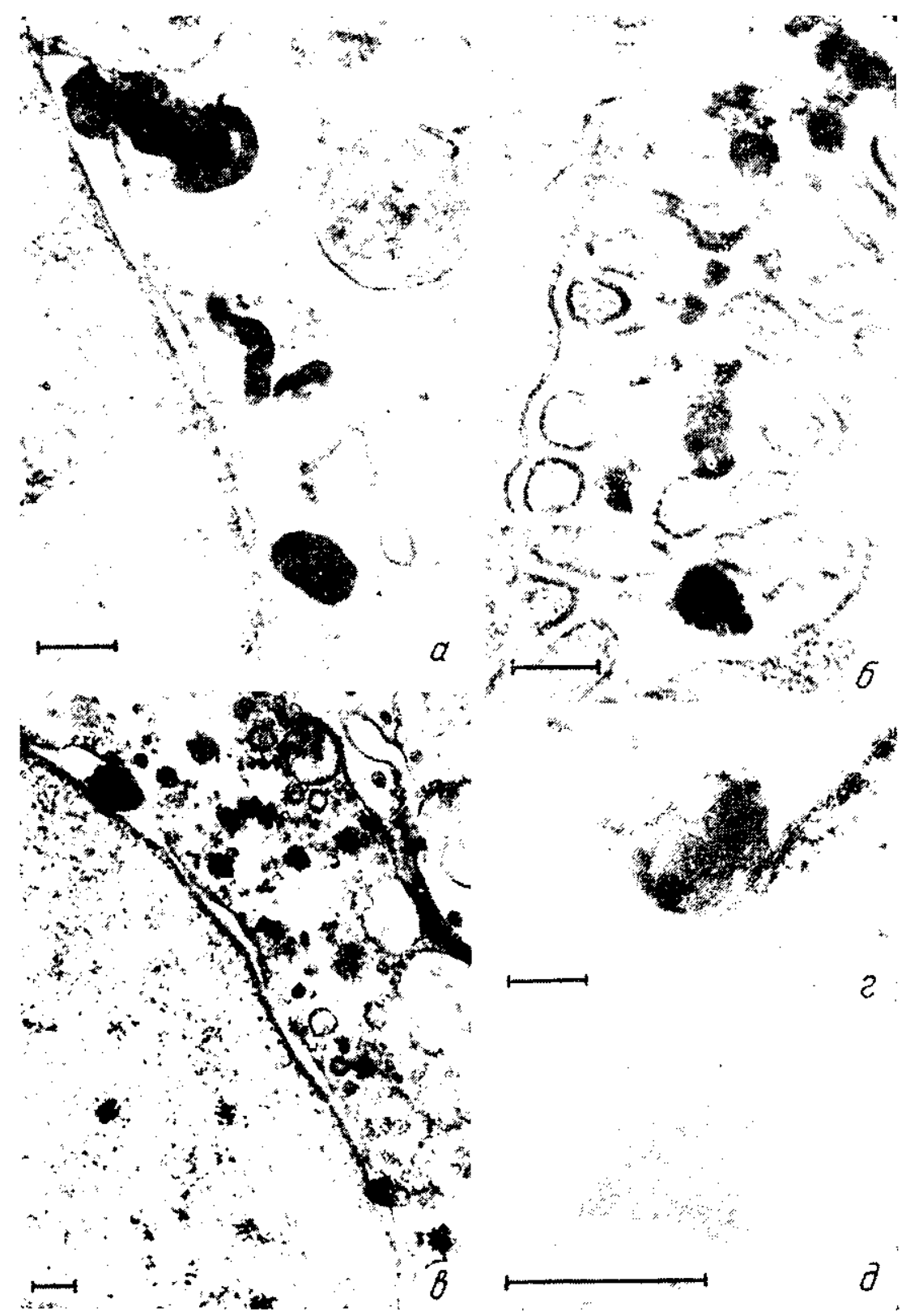

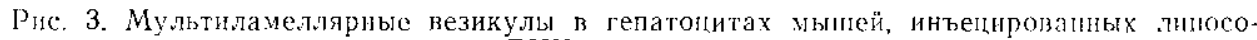
мами, содержащим плазмидиую ДНК: а-вблизи ядериого порового комплекса и в расширении перннуклеарного пространства, $Х 83000$, маслита 0,12 мкм; 6 - в ироснете желиного канальиа, $Х 73000$, масштаб 0,12 мки; ного иространства, $Х 33000$, масштаб 0,15 мкм; $\therefore$,

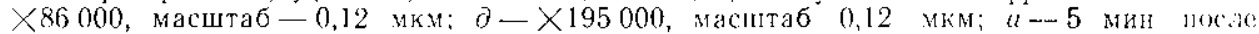
нгъекцин; $\sigma-0-24$ ч после ниъекцин

jig. 3. Multilamellar vesicles in hepatocytes after injection of liposomes with chesinet plasmicl DNA: $a$ - in the vicinity of pore comples and in perinuclear space, 5 mimules after injection, $\times 83000$, bar $0.12 \mu m ; 0-$ in the luminac of bile canticula: $\times 73000$, bar $0.12 \mu \mathrm{m} ; 3$ - in perinuclear space: $\times 33000$, bar $0.15 \mu m ; \therefore$, $\partial$ the enlarged fragments of Fig. 3, $a: 2-\times 86000$, bar $0.12 \mu \mathrm{m} ; 0-\times 195000$, bar $0.12 \mu 11 ; 6-0-24$ luns after injection

ли отмечены ии разу, так же, как ни разу их околоядерное расположение не было сопряжено с каким-либо изменением ядерной мембрапы. Когда же везикулы располагались в просветах перипуклеарного пространства, то стешень расширения последнего не была значительнои, разрывов ядерноӥ оболопки и обобшествления мембран не паблюлали. 


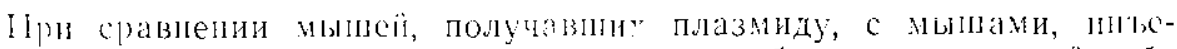

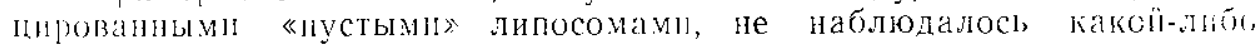

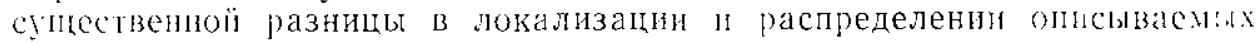
(jo.).

Факт обыаружения олноламельрных везикул в ткан ннтанных животных требует особоӥ осторожности при оценке рсзультатиз оныта. Вероятысе всего, к истинным пипосомам можно этнести ппнц

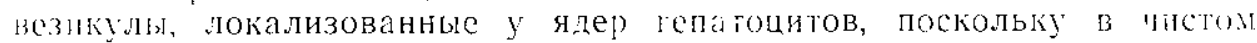
кілтроле они ие встречались. Появление липосом (и «пустых» и «нагруж(нинд) у ядер за столь короткиї с момента индскцин промежу10k времсни хорошо согласуется с паблюдениями авторов работы |12|. Мстодом электронно-микросконической радиоавтографин эти исслепователи показали, что уже через 3 мин после внутривенной инььскцин мынам линосом, содержавпих ДНК, последняя обнаруживалась 13 я.рах. Характерно, что самих липосом вблизи ядер авторам выявить не y:ámels, ибо при радиоавтографнтеской обработке нсстабнлизиро-

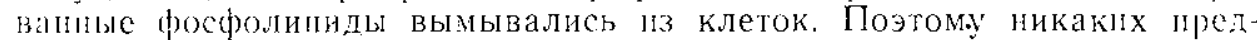
положениї о механизме попаданпя ДНК из липосом в ядра ими не нысказано. В цикле работ [11-13] достоверно продемонстрировано, гто пиутривелно вводимые мыпам лилосомы уже через 20 мил после ннъекции ассоциированы с митохондриями, и эта связь прослеживастся

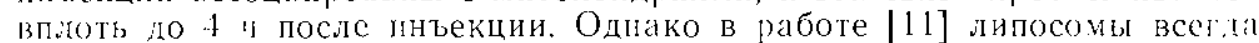
оказывались, заключеныыми в соотетствующие цитоплазиатпческие вакуоли и только такие конгломераты илтернализовались з иатрикс орГанлл. Отсулствие вакуолей вокруг липосом в нашем опите объясиит трудно, так же, вирочем, как и наличис в чистом коптроле определсппоюо количества ПЛ. Нельзя сказать, что подобные картины pance не наблюдались и не оговаривались исследователями. Появление так пазынасмых миелиловых фигур в связи с частичным разрушенпем клеточиюх липопротеидных мембран при альдегидной фнксации - факт обнензвестныї [14]. Одиако в работе [11] подчеркнуто явное отличие yнслнновых фигур от липосом - п по размерам, и по степени пернодниности укладки ламелл, тего мы подтвердить не пожем. ПЛ, паблюdamm!ecs пами, порою неотлитимы от истнныых. Более всего оाи папомншали липосомы на промежуточпй сладин их приготовления, до обработкі ӘДТА (сравнить рис. 2 , а с рис. 1, б). Что же касается уплопения везикул, потери ими просвега полости и сферических отертаний, то эти же особениості отмегали Белицер н др. $[5,6]$ и, очевидло, они возликают при любом взаимодействин фосфолипидных глобул с werkamu

I () всеї вероятности, методнка [9], оптимально выявляюпцая нскусствелю синтезированные фосфолипидные глобулы, не япляется внолне адскватной при их выявлсния в тканях, богатых эндогенными линцами. В пользу этого свидетельствуют нередкие случап выяз'тенн как в опыте, так в в чистом контроле электронноплотных муль-

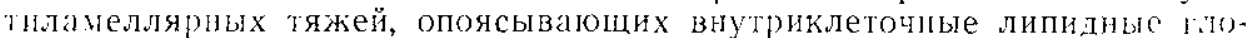
булы (сравнить рис. 2, в, а и 2,3 ). Конфнгурация таких тяжей явно отлитется от липосомной, и их элдогенное происхождение отевидио.

Реакция ультраструктур иа введение плазин-

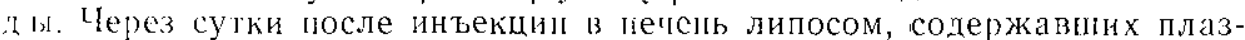
илду, во многих гепатоцитах прослеживались нарушения ультраструктуры иптохондрий: набухание ряда органелл с просвстлсием матрик(а и умеренной фрагментацией крист (рис. 4, a), тастичная погеря двукоштурност митохондриальных мембран (рис, 4, o). В отысыьных органсллах наблюталасы очаговая вакуолизация I мислиннзация (рис. 4, б). Нри иньецировании «пустых» липосом все перелисленные нарушения встретлись с меньшеї частотой и, вероятно, укладывались в рамки обшей неспецифическої реакции органелл на стресс после щрямой инъекции.

Қ 30-тым сут после инъекция липосом, содержавших плазмнду, стуктура ортанелл в большинстве проанализированых клеток вос- 


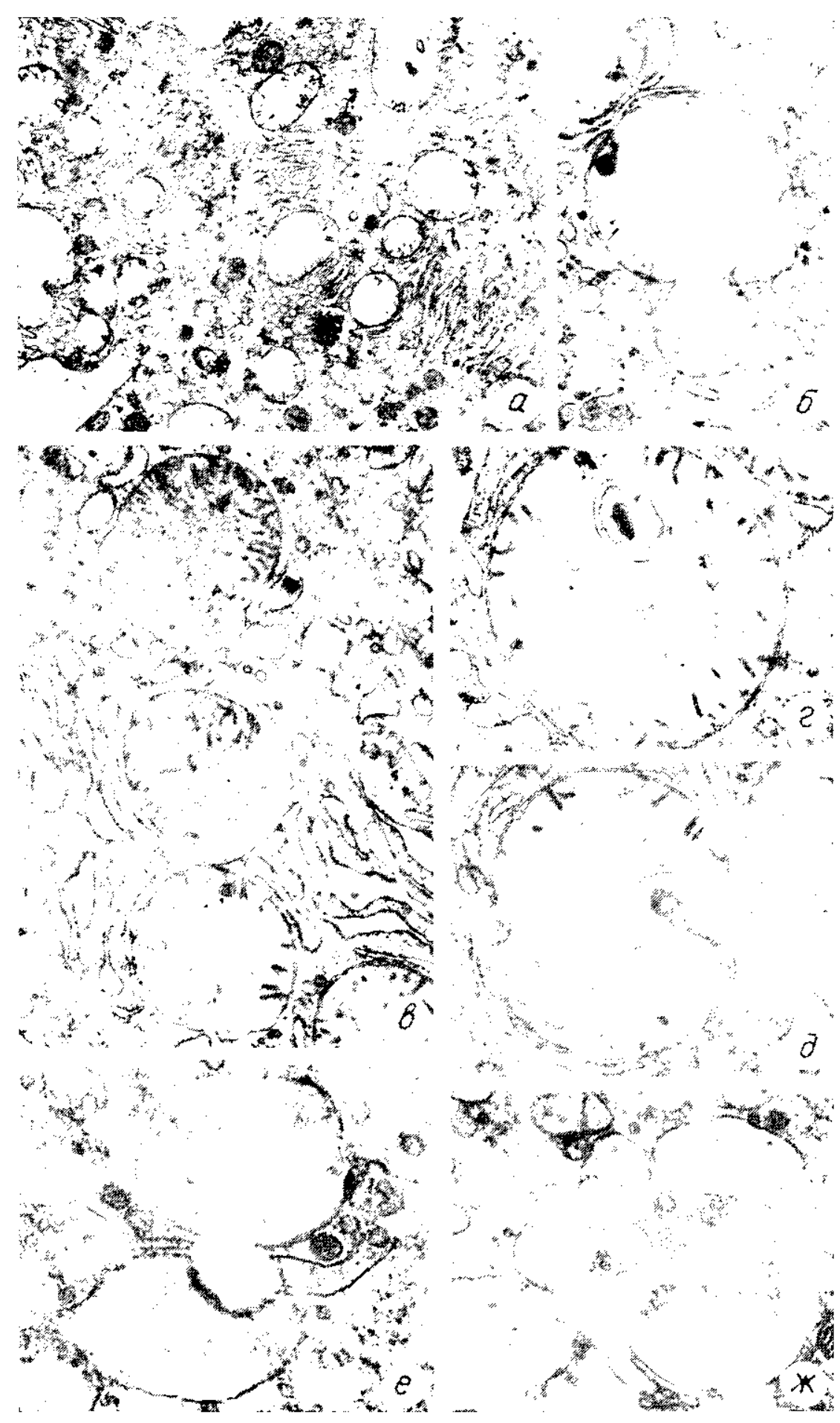

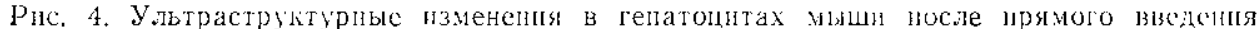
липосом, содержашпх плазмидную ДНК. Измснения в митохондриях: $a-0-24$ ч после введения плазнднои ДНK $(X 10000 ; \times 23000 ; \times 19000$ соответственно); $\therefore$, то же через $30 \mathrm{cy}(X 20000) ;$ гипертрофия аппарата Гольлжи: $e-$ гере; 24 ч $(X 46000) ; \%-30$ ст т после инъеклии $(X 42000)$

Fig. 4. Ultrastructural changes in mice hepatocytes after direct injection of liposomes witl enclosed plasmid DNA: different changes in milochondria: $a-f 3-24$ hours after injection of plasmid DNA $(\times 10000 ; \times 23000, \times 19000$, respectively $) ; 2, \partial-30$ days af ter injection (X20000); Goldgi region hyperthrophy: $c-24$ hours after injection $(X 46000) ; \%-30$ days after injection $(X 42000)$ 
станавливалась, процент набухших митохондрий был меньше, случаи фрагментации крист встречались реже. Однако случаи вакуолизации и миелинизации (рис. 4,2 , д), оставаясь, по-видимому, необратимыми, встречались $\mathrm{c}$ прежней частотой. $\mathrm{y}$ интактных животных миелинизнрованные митохондрии встречались редко, степень миелинизации была незначительной.

Не исключено, что в митохондриях с опрсдсленными нарушениями мембран интенсивнее протекают процессы миелинизации, и такие именио органеллы обладают повышенным сродством к поступающему извне фосфолипндному материалу. Но в таком случае действительно очень трудно отделить причину от следствия, т. е. дифференцировать в опыте истинные липосомы, включившиеся в матрикс, от ПЛ, формирующихся при нарушении целостности митохондриальных мембран из их жс (мембран) фосфолипидного содержимого.

В гепатоцитах мыней, получивших плазмнду, перез сутки поспе иньекции отмечалась значительная гипертрофия элемснтов комплекса Гольджн: рсзкое вздутие секреторных пузырьков с высвобождением в цитоплазму секреторных гранул (рис. 4, е). Напряженность этой органеллы к 30-тым сут после инъекции оставалась высокой (рис. 4, ж). $\mathrm{y}$ животных, которым инъецировали «пустые» липосомы, стросние комплекса Гольджи оставалось в пределах нормы. Функциональное напряжение комплекса Гольджи, вероятнее всего, связано с экспрессией плазмидного гена. Представляется перспективным провесті гистохимическое выявление $\beta$-галактозидазы и сопоставнть ультраструктурное распределение фермента с реакцией данпой органеллы.

В ядрах гепатоцитов никаких существенных нарушений при введении липосом с плазмідой обнаружепо не было. Некоторое расширеине перинуклеарного пространства и незначительное увеличсние числа интерхроматиновых гранул отражали, по-видимому, общее повышение функциональной нагрузки в клетках, активно продуцируюших фермент.

«Ревизия» пругих органелл не выявнла каких-либо существенных нзменений по сравнению с печенью интактных животных.

Авторы выражают благодарность Н. В. Белицер и сотрудникам руководимой ею пабораторин за методическую и консультативную HONOIL.

\section{SOML ULTRASTRUCTURAL ASPECTS OF DIRECT INJECTION OF LIPOSOMES WITH NCLOSED PLASMID DNA INTO MICE LIVER}

K. .H. Bilich, D. .1. Irodon', V. A. Kordium

Itwitute of Molecular Biology and Genetics,

Acaleny of Scienes of the Ukrainian SSR, Kiev

Sum ary

Mfter dired injection of liposomes witl inclosed bacterial $\beta$-galactosidase gene into mico liver the main ultrastructural changes have becn observed in mitochondria and Goldgi reginu. Liposomes themselves were investigated by transmission electron microscopy of ultrathin sections. An attempt was made to elucidate their distributon in mice liver after direct injection.

\section{CIHСOK ЛИТЕРАТУРЫ}

I. Intrahepatic distribution of small unilamellar liposomes as a function of liposomal lipid composition/ H. H. Spanjer, M. V. Galen, F. N. Roerdink et al.//Biochim. et biophys. acta.-- 1986.- 863, N 2.- P. 224-230.

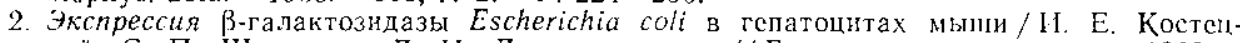
кий. С. П. ІШпилевая, Л. И. Лихатева и лр.// Бнополимеры и клетка.- 1989.5. A $2-$ C. $51-58$. 
3. Марголис Л. В., Брейеельсон Л. Д. Линосомы и их взапмодейтвие с клетками-M. : Наука, 1986.- $240 \mathrm{c}$.

1. Maрголис J. Б. Мехапизмы взаимодействия липосом с кыеткани: перспективы и

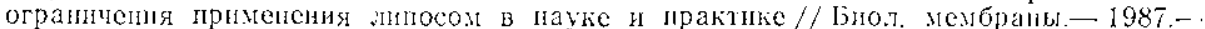
4, № 5- - C. 453-467.

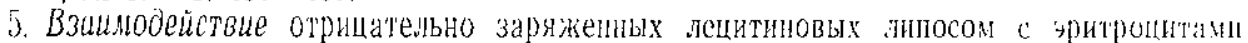
теловека: псследование методом трапсмиссионої электропиой микроскопи ультра-

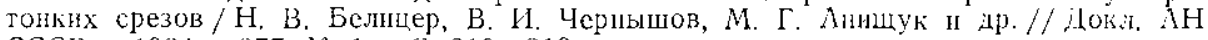
СССР.-1984-- 277, № 1.-C. $210-213$.

6. Interaction of positively charged liposomes with erythrocte membrane An wltastructural study/N. V. Belitser, M. G. Anischuk, V. I. Chernishov, T. R. Korlova// Cell. Biol. Int. Rep-1986-10, N 5.-P. 331-338.

7. Чернытиов В. Н. Козлова Т. Р. Соколов Ю. В. Адсорбиия и с.лияние положительно заряжених линосом с мембрапой эритроцита человека. Электронная микоскопия у.иттратоних срезов // Биол. мембраны. - 1987.-4, № 1.- C. 90-95.

8. Кордюл B. A. Задачи и проблемы гепной терапин// Бнополимеры и клетка.-. 1989 - 5, 스. 2 .... . $5-15$.

9. Takahashi $G$. Tannin-ferrocyanide OsO, method for transmission and scanning clectron microscopy // Proc. XI Int. Congr. on electron micruscopy.-Kyoto, 1986.--345 p.

10. Loud A. V. $\Lambda$ quantitative stereological description of the ultrastructure of normal rat liver parenchimal cell //J. Cell Biol- - 1968.-37, N 1.-P. 27-46.

11. Liposomes injected intravenously into mice associate with liver mitochondria / A. Cudd, H. Lable. M. Gervais, C. Nicolau// Biochim. et biophys. acta.-1984.-774, N 3.-P. $169-180$

12. Cudd A., Nicolau C. Intercellular fate of liposome-encapsulated DNA in mouse liver. Analysis using electron microscope autoradiography and subcellular fractionation // Ibid.- 1985-845, N 4.- P. 477-49!.

13. Cudd A., Nicolau C. Interaction of intravenously injected liposones with liver nitochondria. $A$ fluorescence and electron microscopy study // Ibid.- $1986 \ldots 860, \mathrm{~N} 2 \ldots$ P. $201-214$

14. Гайер Г. Э.ектрония гистохимия.- М. : Мнр, 1974.- 488 с.

Ји-т молекуляр. биотогии и генетики АН УССР, Киев

По.7учене 23.06 .89

X.LK $\quad 577.21: 570.25 .5$

Л. Л. Лукан, Л. Н. Іеборачко, Е. М. Сухора,а, Е. В. Усенко,

И. С. Варзанова, С. В. Подолиская, Т. И. Бужиевская, В. А. Кордюм

\section{ЭКСПРЕССИЯ ГЕНА ИНСУЛИНА ЧЕЛОВЕКА В КУЛЬТИВИРУЕМЫХ КЛЕТКАХ МЛЕКОПИТАЮШИХ}

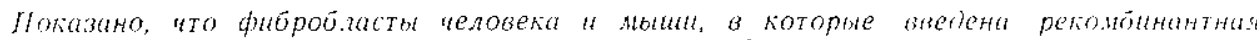

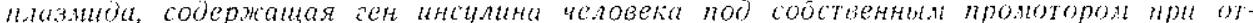

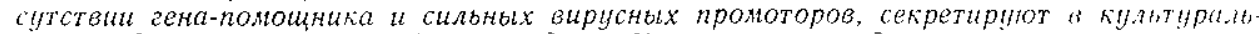

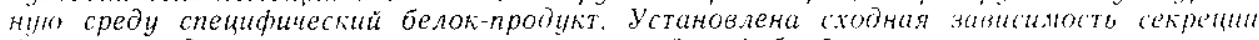

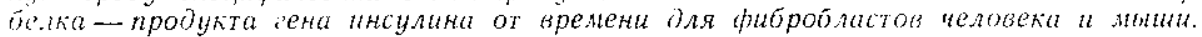

Введение. Разработка методов псиения сахарного диабета, явцюшегося одлим из наиболее распространенных заболеваний, - одна из первоочередных задач биотехнологии в медицине. Биотехнопогия в западиых странах добилась значительных успехов в пролзводстве нн сулина человека тенноинженернми метолами. В будущем ленене этого заболевания, возможно, будет производиться с помощью генной терапии: введение в капсулах или иным путем в организм больного клеток, продуцирующих пнсулин, а также прямое введение нормального гена инсулина в такой молекулярной конструкции, которая обеспечит его экспрессию в клетках больных, в том числе в песпециализированных клетках. Для разработки новых способов лечения важно изучить экспрессию введенного гена инсулина в клетках млекопитающих различного происхождения.

Задачи настоящего исследования следующие: изучение особенностей экспрессии геномного гена инсулина человека в культывирусмых фибробластах человека и мыши и выяснение возможности селекцич клсток, трансформированых по гену инсулина. 